\title{
Sustained remission of Multicentric Castleman Disease in children treated with tocilizumab
}

\author{
C Galeotti , A Boucheron, S Guillaume, I Koné-Paut \\ From 18th Pediatric Rheumatology European Society (PReS) Congress \\ Bruges, Belgium. 14-18 September 2011
}

\section{Background}

Multicentric Castleman Disease (MCD) is an idiopathic lymphoproliferative disorder, exceptionally reported in children, probably due to an increase of interleukin 6 secretion. MCD is characterized by systemic lymphadenopathy and constitutional inflammatory symptoms including severe growth retardation. Previous studies in adult showed that anti-interleukin 6 receptor antibody alleviated symptoms and biochemical abnormalities of MCD.

\begin{abstract}
Aim
We describe efficacy and safety of tocilizumab (TCZ) in two children with MCD. Moreover we describe the long-term effect and dose adjustments in one of them with sustained remission after 3 years.
\end{abstract}

\section{Methods}

MCD was suspected clinically then confirmed histologically in both cases. Tocilizumab was administered intravenously at a dose of $8 \mathrm{mg} / \mathrm{kg}$ every 2 weeks.

\section{Results}

TCZ treatment alleviated fever and restored growth velocity in both patients. In parallel biochemical abnormalities, including hypergammaglobulinemia, increased C-reactive protein (CRP) and erythrocyte sedimentation rate (ESR) returned to normal ranges. For the first patient, the size of abdominal lymph nodes decreased but the splenomegaly persisted. For the second patient, the multiple profound adenopathies persisted and a hepatic node of $7 \mathrm{~mm}$ appeared. The side effects in both cases were mild but sustained thrombocytopenia. Infusions intervals were spaced after 10

\footnotetext{
* Correspondence: caroline.galeotti@gmail.com

Department of Pediatric Rheumatology, CEREMAI, CHU Bicêtre, University of Paris Sud, France
}

C 2011 Galeotti et al; licensee BioMed Central Ltd. This is an open access article distributed under the terms of the Creative Commons Attribution License (http://creativecommons.org/licenses/by/2.0), which permits unrestricted use, distribution, and reproduction in any medium, provided the original work is properly cited. and take full advantage of:

- Convenient online submission

- Thorough peer review

- No space constraints or color figure charges

- Immediate publication on acceptance

- Inclusion in PubMed, CAS, Scopus and Google Scholar

- Research which is freely available for redistribution

\section{Biomed Central}

months for the first patient who had sustained remission since 3 years. The second patient is treated every two

\section{Conclusions}

TCZ is effective and safe in children with MCD. The redundant effect of the drug allows infusion adjustments on a long term-administration. However our observations cannot confirm that TCZ may cure this serious disease.

doi:10.1186/1546-0096-9-S1-P6

Cite this article as: Galeotti et al:: Sustained remission of Multicentric

Castleman Disease in children treated with tocilizumab. Pediatric Rheumatology 2011 9(Suppl 1):P6. 